10IKC-127

\title{
RUTILE AND TITANITE AS THE MINERALS FOR DATING KIMBERLITE EMPLACEMENT AGE: AN EXAMPLE OF AMAKINSKAYA AND TAEZHNAYA PIPES OF MIRNY FIELD, SIBERIA
}

\author{
Agashev A M1, Orihashi Y2, Rotman A Ya3, Pokhilenko N P1, Serov I V3, Tolstov A V4 \\ 1Inst. Geology \& Mineralogy, Novosibirsk 630090, Russia (* correspondence: agashev@igm.nsc.ru) \\ 2Earthquake Research Institute, The University of Tokyo, Yayoi 1-1-1, Bunkyo-ku, Tokyo, 1130032, Japan \\ 3Geo-Scientific Research Enterprise, ALROSA Co Ltd., Mirny, Russia \\ 4Botuobinskaya Enterprise of ALROSA co Ltd, Mirny, Russia
}

Rutile and Titanite could incorporate significant amount of $U$ in their chemical composition and therefore, can be used for age determination by $\mathrm{U}-\mathrm{Pb}$ method. In this study we analyzed these minerals obtained from heavyminerals concentrate of Amakinskaya and Taezhnaya kimberlite pipes (Fig. 1) of Mirny kimberlite field, Siberia.

The Mirny kimberlite field is located in the Southernmost part of Siberian kimberlite province, within the Botuobinskaya anticlinal structure, which divides the Tunguss and Vilyui synclises. The Archean crystalline basement in this area is covered by approximately $1.5-2 \mathrm{~km}$ sequence of sediments. Presently, in the Mirny field, seven kimberlite pipes, one separate dyke and several dykes connected with the pipes are known. A five of these pipes are economically valuable diamond deposits and first of all it is Mir and International pipes. Previously, dating of Mirny field kimberlites emplacement age (Davis et al, 1980) by U-Pb method on zircons shows $360 \mathrm{Ma}$ for Mir and International pipes, but $403 \mathrm{Ma}$ and $450 \mathrm{Ma}$ for Taezhnaya and Amakinskaya pipes respectively. The main purpose of this study is to investigate the applicability of rutile and titanite as the minerals to date kimberlite emplacement age and to clarify the age of Mirny field kimberlites.
The composition of $\mathrm{U}$ and $\mathrm{Pb}$ isotopes of rutile and titanite from kimberlites was determined by laser ablation inductively coupled plasma

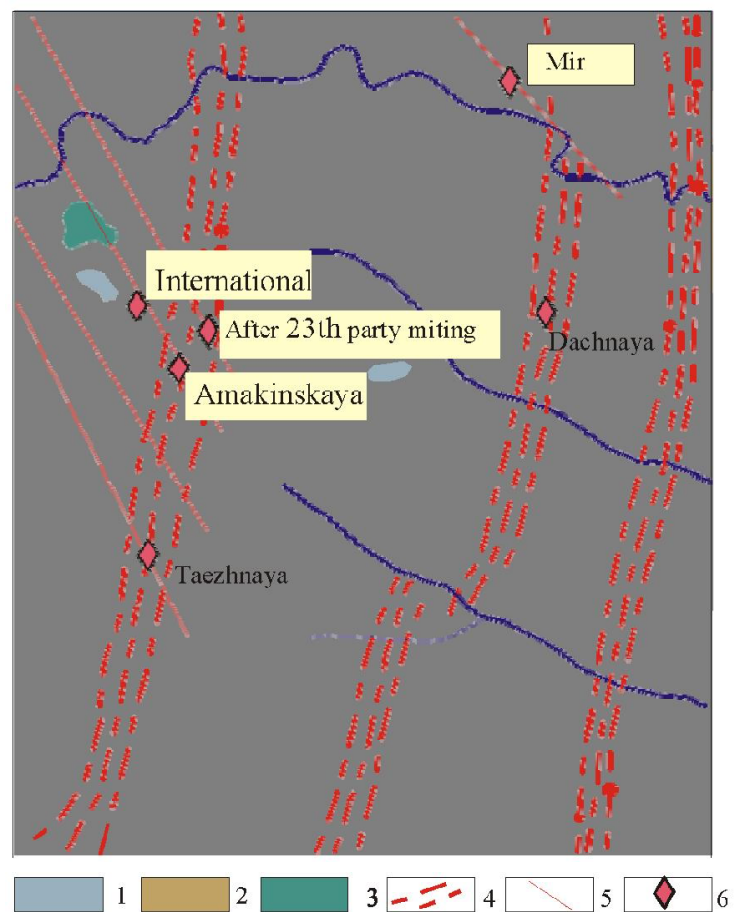

Figure 1. Shematic map of the Mirny kimberlite field 1. Lower Jurassic continental sediments. 2. Lower Paleozoic terrigeniccarboniferous rocks. 3. Trapps. 4. Regional faults. 5. feathering faults. 6. Kimberlite bodies. 


\section{$10^{\text {th }}$ International Kimberlite Conference, Bangalore - 2012}

massDspectrometry (LA ICPDMS). Analytical works were conducted in Tokyo University, Japan. During the sampling, the beam diameter accounted for $30 \mathrm{im}$. The detailed analytical procedure was published elsewhere in Orihashi et al (2008). The quality of analyses was controlled by the international standard of zircon 91500 . The same procedure was previously applied by authors to determine the age of rutile included in diamond (Afanasyev et al, 2009). Measured $\mathrm{U}$ and $\mathrm{Pb}$ isotope ratios vary significantly in different points due to different amounts of common lead admixture as well as due to high heterogeneity of the rutile composition.

\section{DATING RESULTS}

Analytical data shows that both minerals contain significant admixture of common $\mathrm{Pb}$ in their $\mathrm{Pb}$ isotope composition.

To obtain the age information following steps of data treatment was used. At first step we plot the isotope ratios on the Tera-Wasserburg diagram and calculate preliminary isochron age. Then, the 207Pb method (Cox and Wilton 2006) was used to make corrections of the $\mathrm{U} / \mathrm{Pb}$ age of every analyzed point according to the composition and amount of common lead. $207 \mathrm{~Pb} /$ $206 \mathrm{~Pb}$ ratio values of common $\mathrm{Pb}$ was determined according to the upper intersection of the regression line with the $\mathrm{Y}$ axis on the TeraWasserburg diagram. The amount of nonradiogenic lead calculated using this method for every spot analyzed varies significantly from $3 \%$ and up to $75 \%$ of total $\mathrm{Pb}$ concentrations. Error in determination of the $207 \mathrm{~Pb} / 206 \mathrm{~Pb}$ ratio of common lead was estimated according to the lower intersection of regression line with concordia and is included in the error calculation $(2 \sigma)$ of the corrected age. Farther, the corrected age of individual spots was used to calculate the age by weighted average method.

For the rutile grain from Amakinskaya pipe, we obtained the age of $361 \pm 10 \mathrm{Ma}$ on Tera-
Wasserburg diagram and and the same age of 361 \pm 8 by weighted average method (Fig. 2).
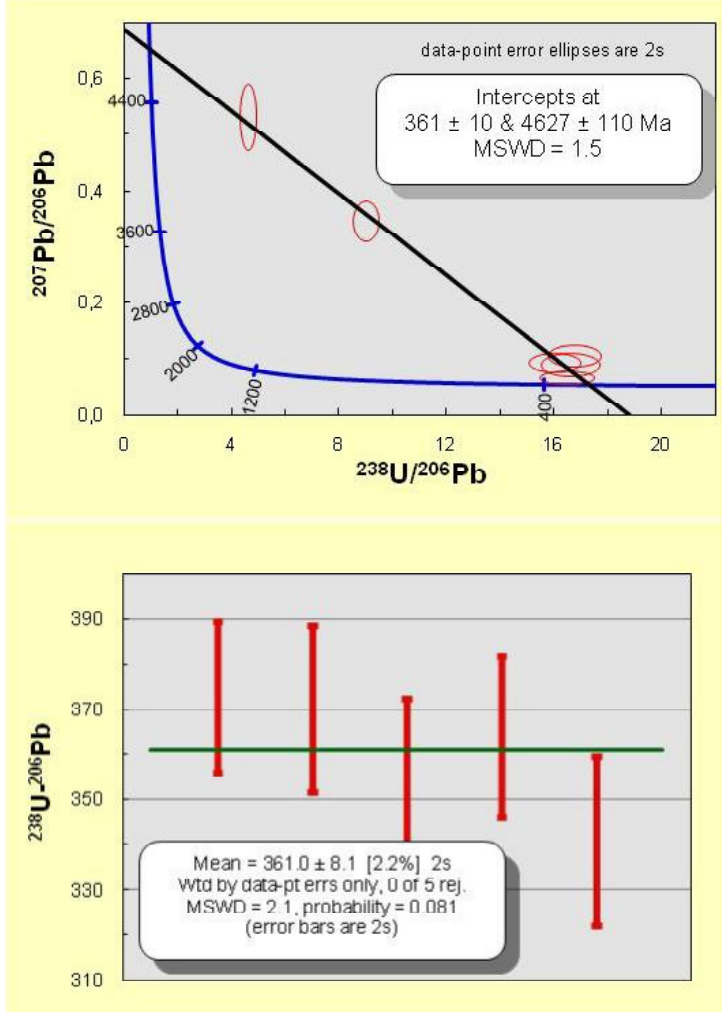

Figure 2. The U/Pb Age for rutile from Amakinskaya pipe.

For the titanite from Taezhnaya kimberlite pipe we obtained $360 \pm 33$ Ma on TeraWasserburg diagram and $357 \pm 12$ by weighted average method (Fig. 3). These ages corresponds to the main episode of kimberlite activity in Siberian platform (Agashev et al, 2004), hence both dated minerals can be used for kimberlite emplacement age determination.

\section{References}

Agashev AM., Pokhilenko NP., Tolstov AV., et al. 2004. New age data on kimberlites from the Yakutian diamondiferous province Doklady Earth Sciences, v 399, 1142-1145 


\section{0 $^{\text {th }}$ International Kimberlite Conference, Bangalore - 2012}
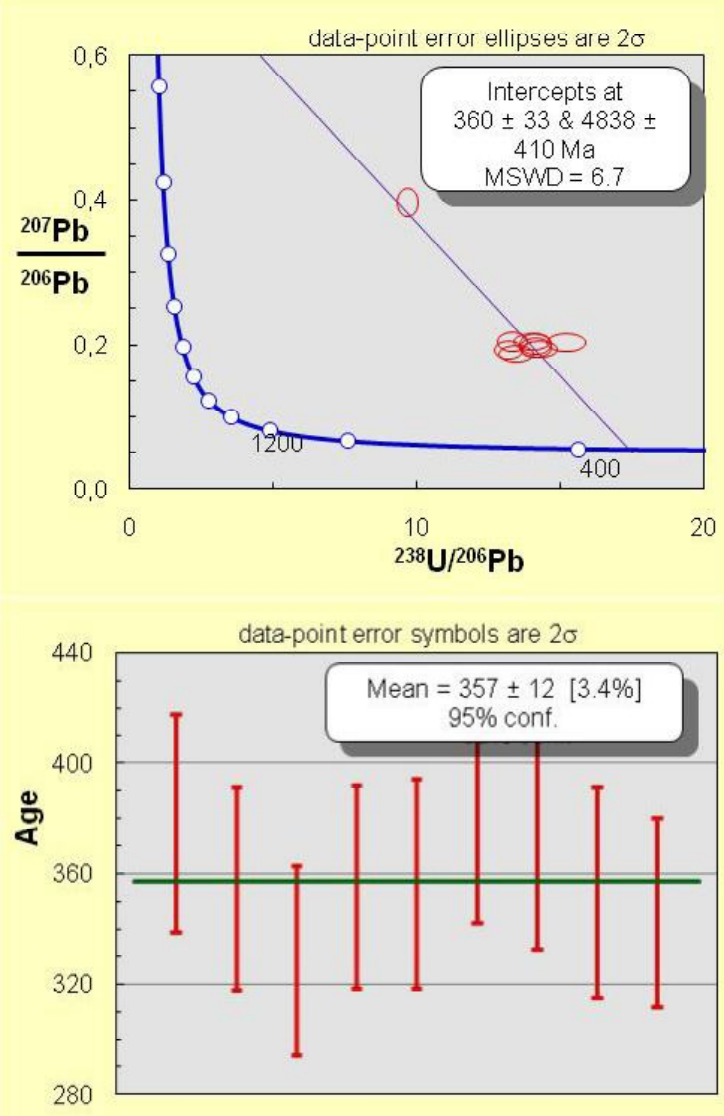

Figure 3. The $\mathrm{U} / \mathrm{Pb}$ age for titanite from Taezhnaya pipe
Afanasyev V. P., Agashev A. M., Orihashi Y., Pokhilenko NP., Sobolev, N.V. 2009. Paleozoic U$\mathrm{Pb}$ age of rutile inclusions in diamonds of the $\mathrm{V}$ VII variety from placers of the northeast Siberian platform. Doklady Earth Sciences, v 428, 11511155 DOI: 10.1134/S1028334X09070253

Cox R. A., Wilton D. H. C. 2006. U-Pb dating of perovskite by LA-ICP-MS: An example from the Oka carbonatite, Quebec, Canada. Chemical Geology, v 235, 21-32 DOI: 10.1016/ j.chemgeo.2006.06.002

Davis, G.L., Sobolev, N.V., and Khar'kiv, A.N. Dokl. New data on Yakytian kimberlites age obtained by U-Pb method on zirkons. Dokl. AN. S.S.S.R. v 254, no. 1, p. 175-179.

Orihashi Y., Nakai S., Hirata T. 2008. U-Pb age determination for seven standard zircons using inductively coupled plasma-mass spectrometry coupled with frequency quintupled $\mathrm{Nd}-\mathrm{YAG}$ (lambda=213 $\mathrm{nm}$ ) laser ablation system: Comparison with LA-ICP-MS zircon analyses with a NIST glass reference material. Resource Geology, V 58, 101-123 